$5 \quad$ Running Title: Increasing R.1 lineage-related COVID-19 cases

Authors:

8 Tsuyoshi Sekizuka, Kentaro Itokawa, Masanori Hashino, Kazuhiro Okubo, Asami Ohnishi,

9 Keiko Goto, Hiroyuki Tsukagoshi, Hayato Ehara, Ryohei Nomoto, Makoto Ohnishi, Makoto

10 Kuroda, Virus Diagnosis Group (NIID Toyama) and COVID-19 Genomic Surveillance Network

11 in Japan (COG-JP).

\title{
Affiliations:
}

14 Pathogen Genomics Center, National Institute of Infectious Diseases, Shinjyuku, Tokyo, Japan

15 (T. Sekizuka, K. Itokawa, M. Hashino, M. Ohnishi, M. Kuroda)

16 Hokkaido Institute of Public Health, Hokkaido, Japan (K. Okubo)

17 Sapporo City Institute of Public Health, Hokkaido, Japan (A. Ohnishi)

18 Ibaraki Prefectural Institute of Public Health, Ibaraki, Japan (K. Goto) 
medRxiv preprint doi: https://doi.org/10.1101/2021.04.04.21254749; this version posted April 7, 2021. The copyright holder for this preprint (which was not certified by peer review) is the author/funder, who has granted medRxiv a license to display the preprint in perpetuity.

It is made available under a CC-BY-NC-ND 4.0 International license.

19 Gunma Prefectural Institute of Public Health and Environmental Sciences, Gunma, Japan (H.

20 Tsukagoshi)

21 Saitama Prefectural Institute of Public Health, Yoshimi, Saitama, Japan (H. Ehara)

22 Kobe Institute of Health, Kobe, Hyogo, Japan (R. Nomoto)

24 Keywords: SARS-CoV-2, COVID-19, spike protein, E484K, R.1, mutation of concern, immune 25 escape, spatiotemporal distribution

\section{Abstract-50 words}

Three COVID-19 waves in Japan have been characterized by the presence of distinct lineage, which shows $25 \%$ abundance, an R.1 lineage carrying the E484K mutation in the spike

31 protein was found to show up to $40 \%$ predominance.

As of March 31, 2021, Japan reported 475,043 cases and 9,175 deaths due to coronavirus disease (COVID-19), some of which were caused by variants of concern (VOCs). We conducted genome surveillance for severe acute respiratory syndrome coronavirus 2 (SARS-CoV-2) with

37 support from local public health centers or laboratory institutes $(1,2)$ and five airport quarantine 38 stations (Narita, Haneda, Nagoya, Kansai, and Fukuoka airports) (3). During the surveillance, we 
medRxiv preprint doi: https://doi.org/10.1101/2021.04.04.21254749; this version posted April 7, 2021. The copyright holder for this preprint (which was not certified by peer review) is the author/funder, who has granted medRxiv a license to display the preprint in perpetuity. It is made available under a CC-BY-NC-ND 4.0 International license .

monitored several VOCs of the PANGO lineage, namely B.1.1.7 (501Y.V1), B.1.351 (501Y.V2), and P.1 (501Y.V3) (4), which have emerged in the past months in all countries. As of March 31, 2021, a notable increase in imported VOC cases has been identified at the airport (123 cases) and domestic (678 cases) quarantines. COG-JP has been monitoring the prevalence of PANGO lineages consistently, from the first COVID-19 case (January 15, 2021) up to recent cases (March 6, 2021) [ $\geq 29 \mathrm{~kb}$ genome in size; in total, 28,350 isolates have been deposited in the Global Initiative on Sharing All Influenza Data (GISAID) EpiCoV database (Appendix Table 1)]. The study protocol was approved by the National Institute of Infectious Diseases, Japan (approval no. 1091). The ethics committee waived the written consent requirement for research on the viral genome sequence.

We have found notable distribution of the PANGO lineage during each COVID-19 wave. Specifically, B.1.1.162, B.1.1.284, and B.1.1.214 were predominant during the first, second, and third waves, respectively (Figure 1). After the first wave (March to April 2020), an effort to monitor airport quarantine was initiated; this measure was successful in reducing the numbers of imported cases (3). Domestic lineages (B.1.1.284 and B.1.1.214), which may have been derived phylogenetically from B.1.1.162 during the first wave, were predominant during the second wave (July to September 2020). However, this was not the case for the other imported lineages. Moreover, B.1.1.214 was the predominant lineage during the peak of the third wave (October 2020 to January 2021) (Figure 1).

Recently, a new R.1 lineage carrying the spike protein mutation E484K has been detected in $<5 \%$ to $>37.6 \%$ of all COVID-19-positive cases; within a span of six weeks (mid-January to early March 2021), there has been a sharp increase in the cases (Figure 1). The spatiotemporal distribution of the PANGO lineage showed that the R.1 cases appear to be predominant in the 
medRxiv preprint doi: https://doi.org/10.1101/2021.04.04.21254749; this version posted April 7, 2021. The copyright holder for this preprint (which was not certified by peer review) is the author/funder, who has granted medRxiv a license to display the preprint in perpetuity.

It is made available under a CC-BY-NC-ND 4.0 International license .

62 Kanto and the northern Tohoku area. Our study, therefore, highlights the region-specific transmission of COVID-19. Indeed, B.1.1.7 cases have been especially predominant in the Kansai area; however, data from the ongoing surveillance of other VOCs will be required to

65 confirm the extensive transmission of B.1.1.7 across Japan.

As a notable feature of VOCs, the B.1.1.7 variant is susceptible to neutralizing antibodies elicited by vaccines using the ancestral spike protein (5). However, there is a greater concern about the other immune evasion mutations, such as the E484K (Glu484 $\rightarrow$ Lys) mutation in the spike (S) protein that is found in the B.1.351 (501Y.V2) variant that emerged in South Africa and the P.1 (501Y.V3) variant in Brazil (6). Indeed, E484K could be a pivotal amino acid substitution with potential for mediating immune escape. Thus far, B.1.1.318, B.1.525, R.1, R.2, and P.2 have been reported as variants carrying the E484K single mutation on the receptor-binding domain. R.1 has been mostly identified in USA (first found on October 24, 2020) and Japan (first found on November 30, 2020). In fact, phylogenetic analysis indicated that both R.1 isolates were highly similar. Thus, the Japanese R.1 isolate might have originated from the R.1 isolate from USA. Conversely, it is possible that the isolates in both countries have been imported from an uncharacterized source in another country, where a potential common ancestor (B.1.1.316) was circulating (Appendix Figure 1).

In conclusion, although VOCs have a marked impact on the number of cases and the severity of COVID-19 across many countries, mutants of concern carrying pivotal mutations should not be disregarded if the latent distribution has been found across the community. We should pay more attention to such potential VOCs to avoid the emergence of mutants of concern. Based on the current epidemiological situation in Japan, with an increase in the circulation of more transmissible lineages, immediate, strong, and decisive public health interventions such as 
medRxiv preprint doi: https://doi.org/10.1101/2021.04.04.21254749; this version posted April 7, 2021. The copyright holder for this preprint (which was not certified by peer review) is the author/funder, who has granted medRxiv a license to display the preprint in perpetuity. It is made available under a CC-BY-NC-ND 4.0 International license .

87

88

89

90

91

92

93

94

contact-tracing, strict quarantine monitoring, and comprehensive real-time genome surveillance have become essential for containment of COVID-19 clusters.

\section{Acknowledgments}

This work was supported by a Grant-in-Aid from the Japan Agency for Medical Research, and the Development Research Program on Emerging and Re-emerging Infectious Diseases [JP20fk0108103 and JP19fk0108104, respectively]. We would like to thank all researchers who deposited and shared genomic data on GISAID (Column H-J in Appendix Table 1). The collaborators are listed in Appendix Table 2.

\section{Author Bio}

Dr. Sekizuka is the chief of the Pathogen Genomics Center, National Institute of Infectious Diseases, Japan. He developed bioinformatics tools to elucidate the transmission dynamics, surveillance, and control of infectious diseases based on pathogen genomics.

\section{References}

1. Itokawa K, Sekizuka T, Hashino M, Tanaka R, Kuroda M. Disentangling primer interactions improves SARS-CoV-2 genome sequencing by multiplex tiling PCR. PLoS One. 2020;15:e0239403.

2. Sekizuka T, Itokawa K, Hashino M, Kawano-Sugaya T, Tanaka R, Yatsu K, et al. A genome epidemiological study of SARS-CoV-2 introduction into Japan. mSphere. 2020;5.

3. Sekizuka T, Itokawa K, Yatsu K, Tanaka R, Hashino M, Kawano-Sugaya T, et al. COVID-19 genome surveillance at international airport quarantine stations in Japan. J Travel Med. 2021;28.

4. Fujino T, Nomoto H, Kutsuna S, Ujiie M, Suzuki T, Sato R, et al. Novel SARS-CoV-2 variant in travelers from Brazil to Japan. Emerg Infect Dis. 2021;27. 
medRxiv preprint doi: https://doi.org/10.1101/2021.04.04.21254749; this version posted April 7, 2021. The copyright holder for this preprint (which was not certified by peer review) is the author/funder, who has granted medRxiv a license to display the preprint in perpetuity. It is made available under a CC-BY-NC-ND 4.0 International license.

111 5. Shen X, Tang H, McDanal C, Wagh K, Fischer W, Theiler J, et al. SARS-CoV-2 variant 112 B.1.1.7 is susceptible to neutralizing antibodies elicited by ancestral spike vaccines. Cell 113 Host Microbe. 2021.

114 6. Altmann DM, Boyton RJ, Beale R. Immunity to SARS-CoV-2 variants of concern. 115 Science. 2021;371:1103-4.

116 7. Julia L. Mullen GT, Alaa Abdel Latif, Manar Alkuzweny, Marco Cano, Emily Haag, 117 Jerry Zhou, Mark Zeller, Nate Matteson, Kristian G. Andersen, Chunlei Wu, Andrew I. Su, 118 Karthik Gangavarapu, Laura D. Hughes, and the Center for Viral Systems Biology 119 outbreak.info. 2020. https://outbreak.info/

120 8. Hadfield J, Megill C, Bell SM, Huddleston J, Potter B, Callender C, et al. Nextstrain: real121 time tracking of pathogen evolution. Bioinformatics. 2018;34:4121-3.

122

123

124

125

Address for correspondence: Makoto Kuroda, Pathogen Genomics Center, National Institute

126 of Infectious Diseases, 1-23-1 Toyama, Shinjuku-ku, Tokyo 162-8640, Japan; email: makokuro@niid.go.jp 
medRxiv preprint doi: https://doi.org/10.1101/2021.04.04.21254749; this version posted April 7, 2021. The copyright holder for this preprint (which was not certified by peer review) is the author/funder, who has granted medRxiv a license to display the preprint in perpetuity. It is made available under a CC-BY-NC-ND 4.0 International license.

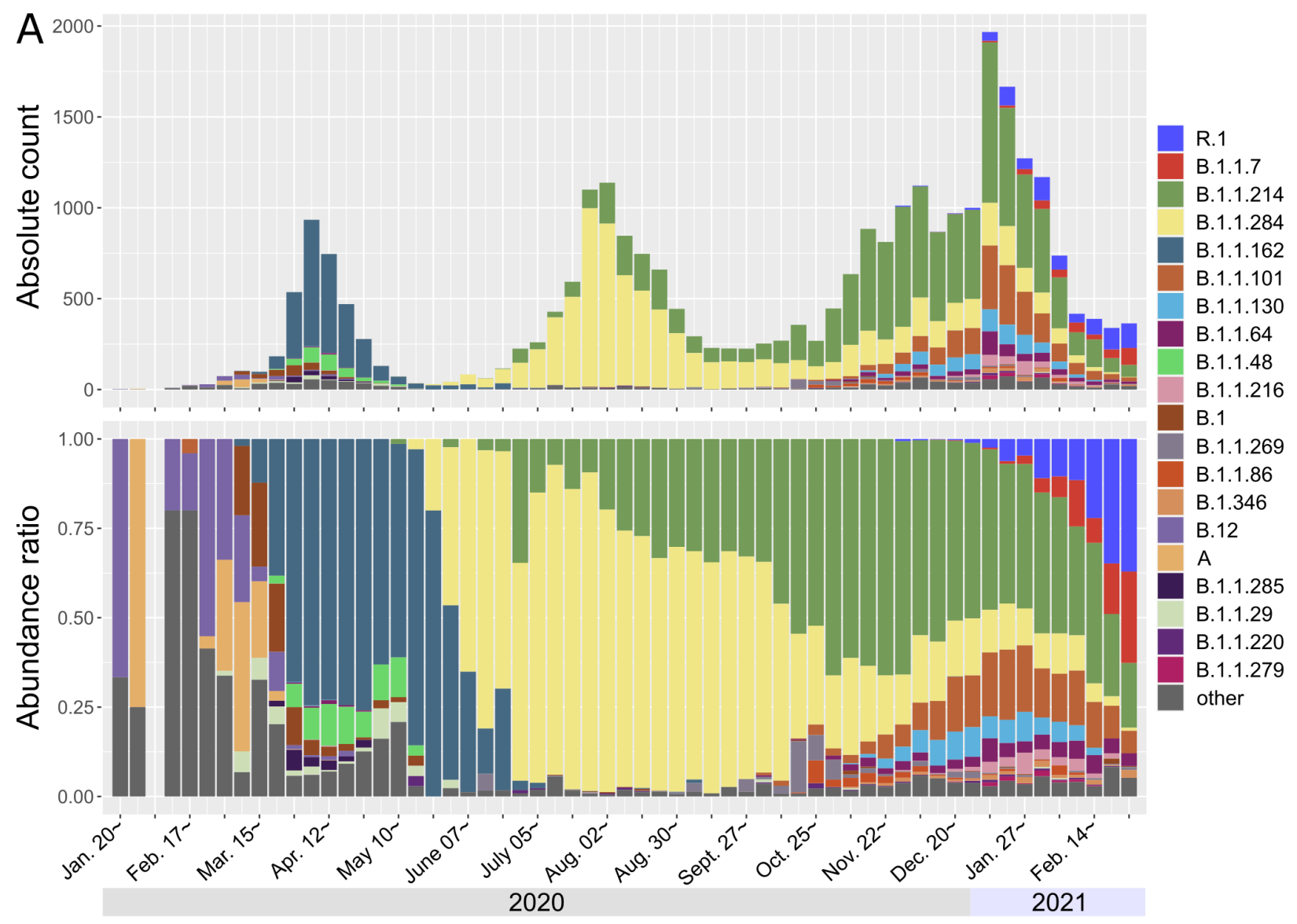

B Figure 1. A spatiotemporal analysis of the SARS-CoV-2 PANGO lineage in Japan.

A) Numbers and B) abundance ratios of whole-genome sequences of SARS-CoV-2 isolates from domestic COVID-19-positive patients in Japan $(\mathrm{n}=28,965)$ were assigned as per the PANGO lineage definition (2021/02/21 version). Top 20 PANGO lineages have been highlighted as per the colors on the right. C) Area-specific lineage percentage is displayed using colored pie charts (shown in panel A and B) from December 2020 to February 2021. 


\section{Appendix Table 1.}

136 Collaboration with local public health institutes and airport quarantines under the COG-JP have 137 been indicated. All SARS-CoV-2 complete genome sequences that we determined and other 138 deposited sequences identified in Japan were retrieved from the GISAID $(n=28,965)$. COG-JP, 139 COVID-19 genomic surveillance network in Japan; GISAID, Global Initiative on Sharing All 140 Influenza Data; SARS-CoV-2, severe acute respiratory syndrome coronavirus 2

\section{Appendix Table 2.}

143 Collaboration between local public health institutes and the COVID-19 genomic surveillance 144 network in Japan (COG-JP) has been shown. 
medRxiv preprint doi: https://doi.org/10.1101/2021.04.04.21254749; this version posted April 7, 2021. The copyright holder for this preprint (which was not certified by peer review) is the author/funder, who has granted medRxiv a license to display the preprint in perpetuity.

It is made available under a CC-BY-NC-ND 4.0 International license .

A)

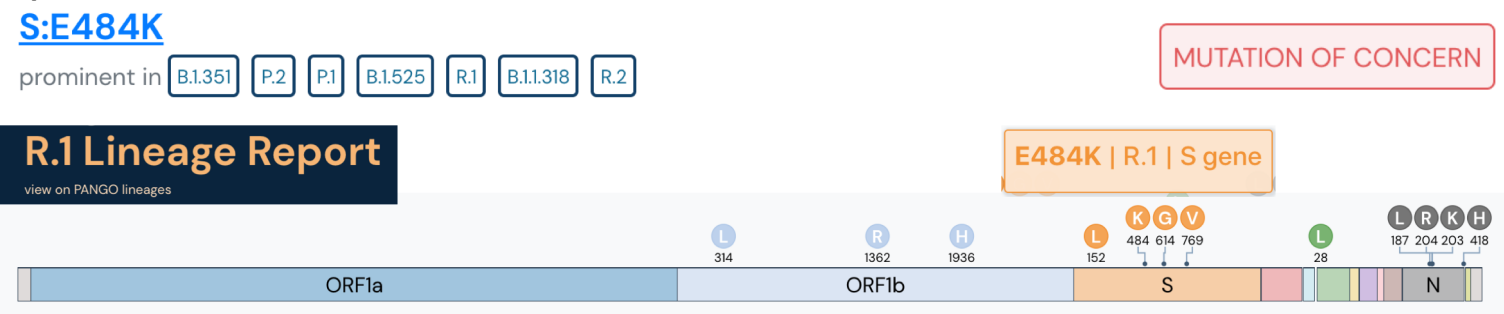

B)

Summary

As of 3 April 2021, 1,600 sequences in the R.1 lineage have been detected since

the lineage was identified:

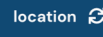

Japan

United States

Belgium

Worldwide

Germany

California, United States

United Kingdom

\begin{tabular}{|c|c|c|c|}
\hline \multicolumn{2}{|r|}{ R.1 found } & \multicolumn{2}{|c|}{ when found ${ }^{2 *}$} \\
\hline total & cumulative prevalence ${ }^{*}$ & first & last \\
\hline 860 & $6 \%$ & 30 Nov 2020 & 17 Mar 2021 \\
\hline 546 & $<0.5 \%$ & 24 Oct 2020 & 24 Mar 2021 \\
\hline 28 & $<0.5 \%$ & 6 Jan 2021 & 17 Mar 2021 \\
\hline 1,600 & $<0.5 \%$ & 24 Oct 2020 & 24 Mar 2021 \\
\hline 45 & $<0.5 \%$ & $4 \mathrm{Feb} 2 \mathrm{O} 21$ & 23 Mar 2021 \\
\hline 4 & $<0.5 \%$ & $24 \operatorname{Dec} 2020$ & 6 Mar 2021 \\
\hline 18 & $<0.5 \%$ & 14 Nov 2020 & 17 Mar 2021 \\
\hline
\end{tabular}

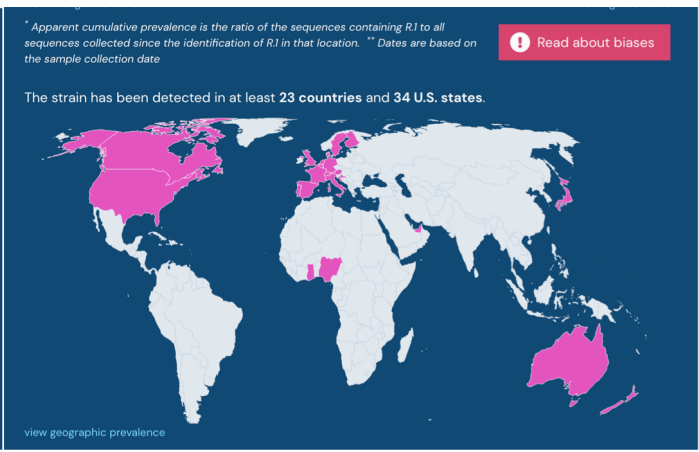

C)
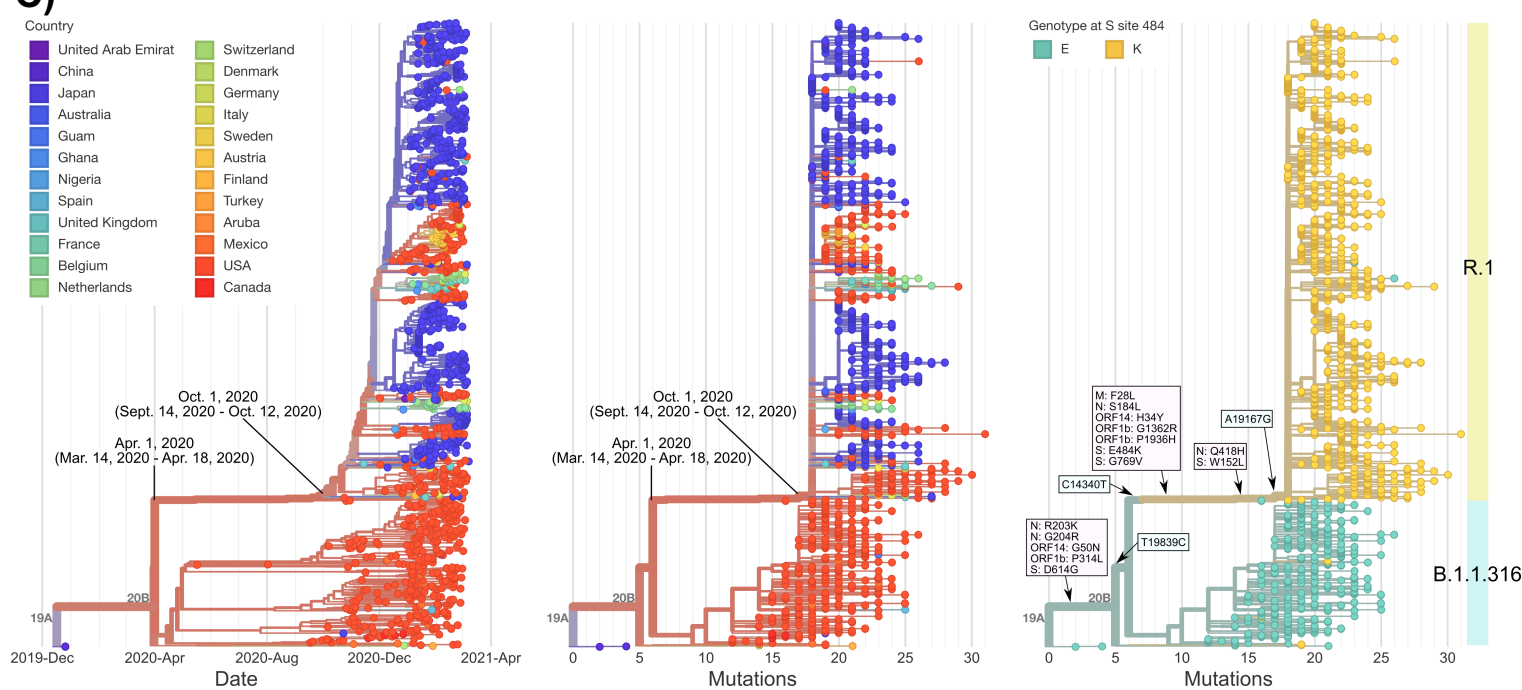

Appendix Figure 1. Summary of SARS-CoV-2 R.1 lineage (April 3rd, 2021)

A) The R.1 lineage has a mutation of concern. The R.1 lineage carries the E484K mutation in the S protein; common genetic features are highlighted above the schematic representation of the SARS-CoV-2 genome structure. B) Current information on the number of cases, country, and first detection date for the R.1 lineage (7). C) Phylogenetic analysis of the R.1 lineage by Nextstrain analysis, along with the B.1.1.316 lineage which is the most recent common ancestor (8). 